\title{
Spatial variability of soil penetration resistance in the lowland area cultivated with soybean
}

\author{
Edgar Salis Brasil Neto ${ }^{1}$ (D) Alexandre Russini ${ }^{1}$ (D) Lúcio de Paula Amaral ${ }^{2}$ (D) \\ Paulo Jorge de Pinho ${ }^{1}$ (D) Marcelo Silveira de Farias $^{3^{*}}$ (D) Robson Giacomeli ${ }^{1}$ (D)
}

\author{
${ }^{1}$ Universidade Federal do Pampa (UNIPAMPA), Itaqui, RS, Brasil. \\ ${ }^{2}$ Departamento de Engenharia Rural (DER), Universidade Federal de Santa Maria (UFSM), Santa Maria, RS, Brasil. \\ ${ }^{3}$ Departamento de Ciências Agronômicas e Ambientais (DCAA), Universidade Federal de Santa Maria (UFSM), 98400-000, Frederico \\ Westphalen, RS, Brasil. E-mail: silveira farias@hotmail.com. .Corresponding author.
}

ABSTRACT: This study determined the spatial variability of soil penetration resistance and yield of the soybean crop in lowland areas. The soil resistance to penetration at four different depths ( 0 to $0.10 \mathrm{~m} ; 0.11$ to $0.20 \mathrm{~m} ; 0.21$ to $0.30 \mathrm{~m}$ and 0.31 to $0.40 \mathrm{~m}$ ), volumetric humidity of the soil at two depths ( 0 to $0.20 \mathrm{~m}$ and 0.21 to $0.40 \mathrm{~m}$ ) and soybean yield were determined in an area of 1.13 hectares, using a sample mesh of $10 \times 10 \mathrm{~m}$. The corresponding data were subjected to descriptive statistical analysis. Pearson's simple linear correlation analysis ( $p \leq 0.05)$ was conducted and the spatial dependence was assessed by analyzing the isotropic semivariograms using spherical, exponential, linear, and Gaussian models. The results showed that the soil penetration resistance increased with depth, with restrictive values to root growth between 0.05 and $0.35 \mathrm{~m}$. There was no correlation between yield and soil penetration resistance, and the semivariograms did not show a defined ascending region regarding the soil penetration resistance data. For the conditions under which the experiment was conducted, the sample 10 $x 10 \mathrm{~m}$ mesh was suitable for assessing the spatial variability of soil resistance to penetration in depths exceeding $0.10 \mathrm{~m}$. Key words: precision agriculture, soil compaction, penetrometry.

\section{Variabilidade espacial da resistência do solo à penetração em área de} várzea cultivada com soja

RESUMO: Este trabalho teve como objetivo identificar a variabilidade espacial da resistência do solo à penetração e na produtividade da cultura da soja, em área de várzea. Foram realizadas determinações de resistência do solo à penetração, em quatro profundidades (0 a 0,10 m; 0,11 a 0,20 m; 0,21 a 0,30 me 0,31 a 0,40 m); umidade volumétrica do solo, em duas profundidades (0 a 0,20 me 0,21 a 0,40 m); e produtividade da soja em uma área de 1,13 hectares, utilizando-se malha amostral de $10 \times 10 \mathrm{~m}$. Os dados foram submetidos à análise estatística descritiva. Realizou-se análise de correlação linear simples de Pearson $(p \leq 0,05)$ e a dependência espacial foi avaliada pela análise de semivariogramas isotrópicos, utilizando os modelos: esférico, exponencial, linear e gaussiano. Os resultados indicaram que, a resistência do solo à penetração aumentou em profundidade, com valores restritivos ao crescimento radicular entre 0,05 e 0,35 m. Não se obteve correlação entre produtividade e resistência do solo à penetração sendo que, para os dados de resistência do solo à penetração, os semivariogramas não apresentaram uma região ascendente definida. Para as condições em que o experimento foi realizado, a malha amostral de $10 x 10 \mathrm{~m}$ utilizada foi adequada para avaliar a variabilidade espacial da resistência do solo à penetração em profundidades superiores a $0,10 \mathrm{~m}$.

Palavras-chave: agricultura de precisão, compactação do solo, penetrometria.

\section{INTRODUCTION}

Brazil is one of the countries in the world with high food production, and is going through the challenge of increasing its productive efficiency owing to the increasing world demand given the environmental, economic, logistic and infrastructure constraints, which have limited the opening of new production areas. Moreover, the cost of production is constantly increasing.

Therefore, to remain competitive in the industry, producers are seeking alternatives by putting new technologies to good use. Using tools such as Precision Agriculture, which consists of a set of technologies that consider spatial variability in production systems, it is possible to apply inputs and management techniques with the maximum technical and economic efficiency (AMADO et al., 2007).

To reduce the production cost of irrigated rice, and driven by the high values paid by soy in the international market, rice farmers have expanded the cultivation of soybeans in lowland areas in a rotation system with rice. Despite the availability of 
genetic materials with high yield potential, the yield of soybean crops in lowland areas is $2,000 \mathrm{~kg} \mathrm{ha}^{-1}$ on average.

The physical characteristics of the soil are some factors affecting the development; and consequently, the productivity of crops. Among these, compaction is a critical factor that deserves special mention because it hinders the development of soybean roots, affecting yield (DALCHIAVON et al., 2011); additionally, it influences the drainage process and contributes to the decrease in the water infiltration capacity of the soil. The main limiting factor for dryland crops in lowland areas is the deficiency in natural soil drainage caused by several factors, such as compaction (PARFITT et al., 2017).

According to classical principles of agricultural experimentation, soil variability occurs randomly; however, the variability of the chemical and physical properties is correlated with other variables (REICHARDT et al., 1986). Compaction has been widely studied in the context of Precision Agriculture and the most commonly used indicator for its measurement is the soil penetration resistance (SPR) employing penetrometer (MOLIN et al., 2015).

Although, some studies on this topic evaluate the compaction of soil in highlands, note that research on soil compaction with crop rotations in lowland areas is still uncommon in Brazil. Therefore, this study determined the spatial variability of SPR and yield of soybean crops in lowland areas.

\section{MATERIALS AND METHODS}

The experiment was conducted in a commercial cultivation area for irrigated rice in the municipality of Itaqui, located on the western border of the State of Rio Grande do Sul (29 $19^{\circ}$ '09.17' S; $56^{\circ} 34^{\prime} 21.35^{\prime \prime} \mathrm{W} ; 55 \mathrm{~m}$ altitude). According to the Köppen climate classification, the climate is of the Cfa type, subtropical with hot summers, without a well-defined dry season.

The soil is classified as dystrophic Haplic Plinthosol (SANTOS et al., 2018), characterized as deep soils, imperfectly or moderately drained, and formed under conditions of restriction to the percolation of water. The textural class was classified as the sandy clay franc, according to the granulometric analysis.

The soybean crop was sowed in the harvest season following irrigated rice implemented under the soil preparation conventional system. To prepare the area, after the rice harvest, we used a hydraulic leveling planer on the vegetable remains, to undo the remaining level curves and fix the microrelief.
The 1.13 hectares experimental area was mapped using a GNSS navigation receiver (C/A Code), with a positional accuracy of 3 to $10 \mathrm{~m}$. A sample quadrangular mesh with a size of $10 \times 10 \mathrm{~m}$ ( 0.01 hectares) was generated in this perimeter, using a computational program $C R$ - Campeiro 7, creating 113 sampling points. To avoid a possible overlap of points resulting from the positional accuracy of the GNSS receiver and the density of the sample mesh, the grid was staked and the distance between the points was obtained using a measuring tape.

To determine the SPR, five measurements were made at each sampling point: the central point and the other at a radius of two meters from this point (CANCIAN, 2015). The measurements were taken using a digital electronic penetrometer, Eijkelkamp brand, Penetrologger model, to depths of 0 to 0.10 $\mathrm{m}$ (SPR10); 0.11 to $0.20 \mathrm{~m}$ (SPR20); 0.21 to $0.30 \mathrm{~m}$ (SPR30); and 0.31 to $0.40 \mathrm{~m}$ (SPR40).

The SPR data were classified according to the divisions adapted by BEUTLER et al. (2001), as extremely low (SPR $<0.01 \mathrm{MPa})$; very low $(0.01$ $<\mathrm{SPR}<0.1 \mathrm{MPa})$; low $(0.1<\mathrm{SPR}<1.0 \mathrm{MPa})$; moderate $(1.0<\mathrm{SPR}<2.0 \mathrm{MPa})$; high $(2.0<\mathrm{SPR}$ $<4.0 \mathrm{MPa})$; very high $(4.0<\mathrm{SPR}<8.0 \mathrm{MPa})$; and extremely high (SPR > 8.0 MPa).

To determine the volumetric water content of the soil $\left(\mathrm{m}^{3} \mathrm{~m}^{-3}\right)$, we used a TDR probe from the Campbell Scientific brand, HydroSense model. The moisture was measured at depths of 0 to 0.20 $\mathrm{m}$ (U20) and 0.21 to $0.40 \mathrm{~m}$ (U40) at the sampling points. For calibrating the TDR probe, we used six undisturbed soil samples collected at each depth, and the gravimetric moisture and soil density were determined according to DONAGEMA et al. (2011). The number of undisturbed samples for calibrating the TDR probe was determined because of the small size of the area and the density of the sample mesh used. Based on the methodology proposed by DONAGEMA et al. (2011), the gravimetric moisture was transformed into volumetric moisture using the soil density values.

To ascertain the yield of the soybean crop, a two meter manual harvest in two central rows was conducted, totaling an area of $4.60 \mathrm{~m}^{2}$ for each sampling point. The grain yield values were obtained by weighing, corrected for a moisture content of $13 \%$, and converted to yield in $\mathrm{kg} \mathrm{ha}^{-1}$.

The data were the objects of the descriptive statistical analysis to verify their dispersion. We used the Action Stat Pro software for this purpose, obtaining the following statistical parameters: mean, median, standard deviation, maximum and minimum 
value, coefficients of variation (CV), asymmetry (Cs), and kurtosis $(\mathrm{Ck})$.

To verify the normality of the data, we used the Kolmogorov-Smirnov test and applied a BoxCox transformation when necessary. Pearson's simple linear correlation $(\mathrm{p}<0.05)$ analysis was conducted to verify the correlation, where the SPR, soil moisture, and soybean yield data for each sampling point were compared. For the $\mathrm{CV}$, the classification proposed by WARRICK \& NIELSEN (1980) was followed as low $(\mathrm{CV} \leq 12 \%)$, medium $(12 \%<\mathrm{CV}<60 \%)$ and high $(\mathrm{CV} \geq 60 \%)$.

The spatial dependence was evaluated by analyzing semivariograms adjusted by the Gs+ software using isotropic semivariograms and the spherical, exponential, linear, and gaussian models. The best-adapted model was initially chosen based on the observation of the best determination coefficient and the lowest sum of squares of the residue, with subsequent confirmation of the model by the cross-validation method, determining the best correlation coefficient. The following parameters were defined in the adjusted semivariograms: the nugget effect $\left(\mathrm{C}_{0}\right)$, plateau $\left(\mathrm{C}_{0}+\mathrm{C}\right)$, and range of spatial dependence $\left(\mathrm{A}_{0}\right)$.

To analyze the degree of spatial dependence, the classification proposed by CAMBARDELLA et al. (1994) was considered as follows: strong spatial dependence of the semivariograms that present a degree of spatial dependence (proportion of the nugget effect on the value of the plateau) $\leq 0.25$; moderate between 0.25 and 0.75 ; and weak for a value $>0.75$.

The maps of the analyzed variables were generated by the computational program $C R$ - Campeiro 7, employing the geostatistical interpolation of the punctual ordinary kriging technique. The inverse distance weighting (IDW) method was applied for the variables at which it was impossible to adjust the semivariograms.

\section{RESULTS AND DISCUSSION}

Table 1 presents the descriptive analysis of the soil physical attributes and soybean yield. All the evaluated variables were normal, except for the humidity, at a depth of 0.21 to $0.40 \mathrm{~m}$ (U40).

For all events, the average showed values close to the median. All the other variables showed weak positive asymmetry, except for the SPR10 variable, indicating a concentration of values lower than the average. These results are similar to those obtained by CAMPOS et al. (2012) and CANCIAN (2015) when investigating the spatial variability of the SPR in a Haplic Cambisol and a typical dystrophic Red Latosol, respectively.

The amplitudes of the values between the maximum and minimum limits for the attributes being studied indicated that it resulted in errors as measures of management based on the average of the observations. The amplitude in the soil attributes has been observed in other studies (BOTTEGA et al., 2013; CHERUBIN et al., 2011; CANCIAN, 2015), verifying the significance of the geostatistical study.

For the CV, we observed low and average variability for the $\mathrm{U} 20$ and other attributes, respectively. Other studies also present values of SPR classified as average variability (GREGO \& VIEIRA, 2005; AMADO et al., 2007; CARVALHO et al., 2008). The data on the physical properties in an area may be

Table 1 - Descriptive analysis of soil penetration resistance $(\mathrm{MPa})$, volumetric water content of the soil $\left(\mathrm{m}^{3} \mathrm{~m}^{-3}\right)$ and soybean yield $\left(\mathrm{kg}^{-1}\right)$.

\begin{tabular}{lccccccccc}
\hline Variable & Average & Median & $\mathrm{S}^{(1)}$ & Max. $^{(2)}$ & Min. ${ }^{(3)}$ & $\mathrm{CV}^{(4)}$ & $\mathrm{Cs}^{(5)}$ & $\mathrm{Ck}^{(6)}$ \\
\hline SPR10 & 1.778 & 1.741 & 0.368 & 2.534 & 1.023 & 20.696 & -0.037 & -0.864 \\
SPR20 & 2.336 & 2.308 & 0.473 & 4.072 & 1.489 & 20.272 & 0.609 & 0.683 \\
SPR30 & 2.403 & 2.173 & 0.729 & 4.461 & 1.28 & 30.334 & 0.742 & -0.091 \\
SPR40 & 2.021 & 1.87 & 0.604 & 3.999 & 1.123 & 29.920 & 1.080 & 1.078 \\
U20 & 0.266 & 0.263 & 0.015 & 0.321 & 0.236 & 5.648 & 0.933 & 1.201 \\
U40 & 0.307 & 0.29 & 0.05 & 0.461 & 0.243 & 16.53 & 0.987 & 0.279 \\
PROD & 1078.344 & 1034.708 & 324.186 & 2016.176 & 414.510 & 30.063 & 0.281 & -0.234 \\
\hline
\end{tabular}

Legend: (1) Standard deviation; (2) Maximum; (3) Minimum; (4) Coefficient of Variation; (5) Asymmetry coefficient; (6) Kurtosis coefficient. 
quite variable, resulting in a large total amplitude and high variation coefficients (MESQUITA et al., 2003).

The SPR was considered moderate at the SPR10 depth, and high $(>2.0 \mathrm{MPa})$ at the deepest layers of the soil; this value is considered a critical limit for the normal development of the root system (RICHART et al., 2005). Therefore, the area under study presents SPR data that may interfere in the development of cultures, even at the SPR10 depth, when considering the analysis of the maximum value for this attribute.

The lowest SPR values in the superficial layer may be explained by the constant mobilization of soil. This effect is caused by the shaft of seed drill machines as well as the presence of the root system of the plants and higher biological activity of the soil (SANTOS et al., 2015). However, the subsurface compaction may be attributed to conventional tillage (GREGO \& VIEIRA, 2005), the type of management adopted in the experimental area of this research.

TAVARES et al. (2014), when investigating the spatial variability of soil penetration resistance and the moisture of a FluvicNeosol, obtained a CV behavior for SPR similar to that observed in this study, increasing with depth, as well as higher values of $\mathrm{CV}$, for the 0.21 to $0.30 \mathrm{~m}$ layer.

However, the CV for the SPR was greater at the 0 to $0.10 \mathrm{~m}$ layer and decreased with depth according to the following: CARVALHO et al. (2008) on the spatial variability of soil's mechanical resistance to penetration and water content of the soil in Red clayey Latosol; CHERUBIN et al. (2011) on the variability of soil resistance to penetration relative to the sample mesh, in a typical dystrophic Red Latosol; CAMPOS et al. (2012) on the spatial variability of soil resistance to penetration and moisture in a Haplic Cambisol; and CANCIAN (2015), who studied the spatial and vertical variability of the resistance to penetration, particle size, and soil moisture, in a typical dystrophic Red Latosol.

By analyzing table 2, it can be inferred that there was a positive correlation between SPR and soybean yield, at depths of 0.21 to $0.30 \mathrm{~m}$ and 0.31 to $0.40 \mathrm{~m}$. Several studies have not been conclusive and, the correlation between the SPR and soybean yield has been low (GIRARDELLO et al., 2014). While evaluating the soybean yield relative to the SPR for a no-tillage system in a dystroferric Red Latosol DALCHIAVON et al. (2011) stated that the attributes exhibited a negative correlation of $21 \%$ in the 0.10 to $0.20 \mathrm{~m}$ layer, but no correlation was observed in the 0 to $0.10 \mathrm{~m}$ and 0.20 to $0.30 \mathrm{~m}$ layers.

It is expected that the correlation between the soybean yield and SPR is negative, that is, the yield will decrease with the increase of SPR. From the data presented, it can be deduced that there was a significant correlation between the yield and SPR at depths of 0.21 to $0.30 \mathrm{~m}$ and 0.31 to $0.40 \mathrm{~m}$; however, this correlation was positive, which was the opposite of what was expected. This behavior may be explained by the fact that the cultures suffered a severe pest attack (Euschistus heroes and Cercosporakikuchii) in the vegetative stages R5 and R6, compromising the yield.

For the correlation between SPR and volumetric water content of the soil, it was reported

Table 2 - Correlations between soil resistance to penetration, volumetric water content of the soil and soybean yield

\begin{tabular}{|c|c|c|c|c|c|c|c|}
\hline Attribute & SPR10 & SPR20 & SPR30 & SPR40 & U20 & U40 & PROD \\
\hline SPR10 & 1 & & & & & & \\
\hline SPR20 & $37^{*}$ & 1 & & & & & \\
\hline SPR30 & 2 & $57^{*}$ & 1 & & & & \\
\hline SPR40 & 3 & $37^{*}$ & $80^{*}$ & 1 & & & \\
\hline U20 & -2 & $-45^{*}$ & $-34^{*}$ & $-19^{*}$ & 1 & & \\
\hline U40 & -1.5 & $-34^{*}$ & $-46^{*}$ & $-40^{*}$ & $32^{*}$ & 1 & \\
\hline PROD & -5 & -7.6 & $18^{*}$ & $34.5^{*}$ & 15.4 & -12 & 1 \\
\hline
\end{tabular}

Legend: SPR10 - Soil penetration resistance, at a depth of 0 to $0.10 \mathrm{~m}$; SPR20 - Soil penetration resistance, at a depth of 0.10 to $0.20 \mathrm{~m}$; SPR30 - Soil penetration resistance, at a depth of 0.20 to $0.30 \mathrm{~m}$; SPR40 - Soil penetration resistance, at a depth of 0.30 to $0.40 \mathrm{~m}$; U20 Volumetric water content of the soil, at a depth of 0 to $0.20 \mathrm{~m}$; U40 - Volumetric water content of the soil, at a depth of 0.20 to $0.40 \mathrm{~m}$; PROD - Soybeanyield. "Pearson's simple linear Correlation significant at the $5 \%$ level of error probability. 
that all other depths except for SPR10 exhibited a negative correlation between the attributes, namely, $45 \%$ for SPR $20,46 \%$ for SPR 30 , and $40 \%$ to RM 40 . This behavior occurs because the SPR is influenced by the water content of the soil, where the cohesion between the soil particles decreases as the water content increases, reducing the SPR (BEUTLER \& CENTURION, 2004; SILVA et al., 2004).

Table 3 shows the results of the geostatistical parameters, obtained by adjusting the semivariograms. Note that all other attributes except for SPR10 exhibited a moderate or strong spatial dependence. The attributes presented a high coefficient of determination for the adjusted semivariograms, which indicates that the models employed determined the spatial variability of the attributes.

The models adjusted for the SPR were of the exponential type and presented a lower range distance, compared with the models adjusted to U, which were of the spherical type (Table 3). These are the most common for adjusting semivariograms for soil properties (GREGO \& VIEIRA, 2005), and the exponential type represents processes with a greater loss of similarity with the distance (GREGO et al., 2014).

For the variables, where it was possible to adjust the semivariogram, the range was higher than the mesh used, ensuring that the neighboring points located within this radius could be used to estimate values for any point between them. The spatial dependence range defines the maximum distance to which a variable is spatially correlated (SILVA et al., 2017), distinguishing spatially structured behavior from the random one (ANDRIOTTI, 2003).

Figure 1 shows the adjusted semivariograms for soil penetration resistance, the volumetric water content, and yield. There was no semivariogram adjustment for SPR10, which showed a pure nugget effect, as obtained by SILVA et al. (2017). The nugget effect is a significant measurement that indicates the non-explained variability, which may occur because of measurement errors and non-detected microvariations (CAMBARDELLA et al., 1994).

The moisture semivariograms were the best structured, followed by those of the soybean yield because they presented ascending regions with many data pairings and an evident plateau formation. However, the SPR semivariograms did not have a defined ascending region, and their values may have been more random owing to the higher occurrence of pairings in the plateau region, i.e., random behavior.

An accurate semivariogram adjustment should present a determination coefficient equal to one, with the linear coefficient equal to zero and the angular coefficient equal to one (ROBERTSON, 2008). For the adjusted models (Table 4), the linear coefficients of SPR ranged from -0.15 to 0.289 , the moisture content from 1.57 to 4.05 , and the yield was 131.72. The angular coefficients ranged from 0.788 to $1.062,0.869$ to 0.941 , and 0.878 for SPR, moisture content, and yield, respectively. Considering these values, it is possible to determine a proper adjustment for the semivariograms, with proximity to the real and estimated values. The estimated yield may have had its estimate hindered by the high randomness of the data, resulting from the attack of pests; however, it presented a good angular coefficient. Regarding the coefficient of determination of regression, the lower values are similar to those obtained by SANTOS et al. (2005).

While analyzing the SPR at a depth of 0 to $0.10 \mathrm{~m}$, virtually every area presents values below the critical limit of $2 \mathrm{MPa}$ (Figure 2a). The values of SPR

Table 3 - Geostatistical parameters obtained from semivariograms adjustments.

\begin{tabular}{|c|c|c|c|c|c|c|c|}
\hline Variable & Model & Pepita Effect $\left(\mathrm{C}_{0}\right)$ & $\begin{array}{l}\text { Baseline } \\
\left(\mathrm{C}_{0}+\mathrm{C}\right)\end{array}$ & $\begin{array}{c}\text { Range }(\mathrm{m}) \\
\left(\mathrm{A}_{0}\right)\end{array}$ & $\mathrm{R}^{2}$ & $\mathrm{IDE}^{(1)}$ & Spatial Dependency Class \\
\hline SPR10 & Linear & 0.139 & 0.139 & - & 0.597 & - & $\mathrm{EPP}^{(2)}$ \\
\hline SPR20 & Exponential & 0.037 & 0.246 & 10.9 & 0.787 & 0.15 & Strong \\
\hline SPR30 & Exponential & 0.292 & 0.585 & 20.3 & 0.737 & 0.50 & Moderate \\
\hline SPR40 & Exponential & 0.029 & 0.356 & 22.8 & 0.254 & 0.08 & Strong \\
\hline $\mathrm{U} 20$ & Spherical & 0.000109 & 0.000236 & 68.0 & 0.935 & 0.46 & Moderate \\
\hline U40 & Spherical & 0.00143 & 0.00287 & 64.7 & 0.860 & 0.50 & Moderate \\
\hline PROD & Exponential & 60700 & 124300 & 34.7 & 0.975 & 0.49 & Moderate \\
\hline
\end{tabular}

Legend: (1) Spatial Dependency Index; (2) Pure Pepita Effect. 


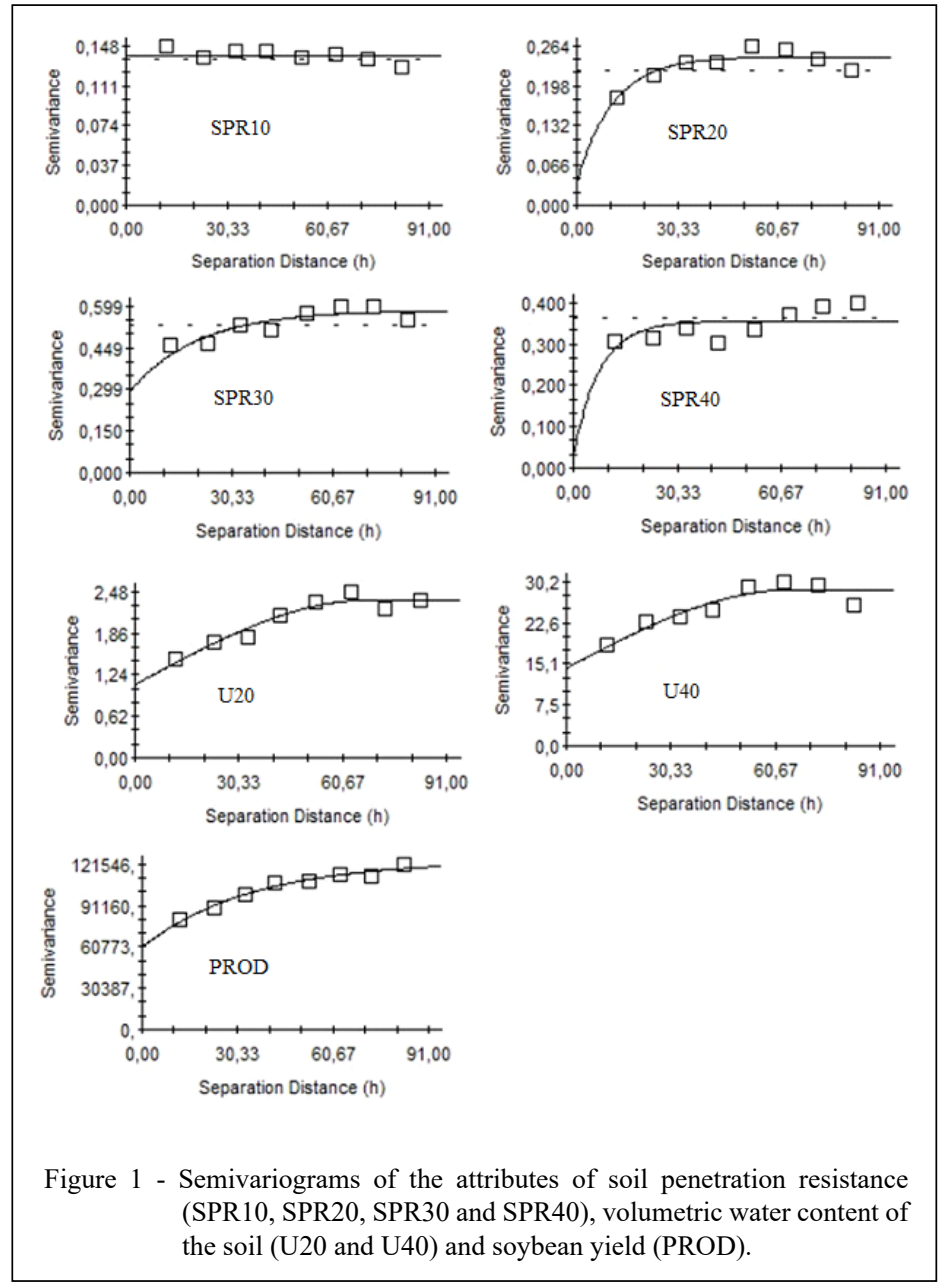

above 2 MP; although, focused on a smaller area, match those at SPR20 and SPR30. This information is important in the case of mechanical operation for the rupture of the compacted layer. Conventionally, the soil attributes do not exhibit a purely random spatial variation and by mapping the areas that require greater care, we will obtain more efficient resource management (SILVA et al., 2017).

For the spatial determination of data on the soil's volumetric water content (Figure 2b),

Table 4 - Cross-validation parameters for semivariograms adjusted for the attributes of soil penetration resistance (SPR20, SPR30 and SPR40), volumetric water content of the soil (U20 and U40) and soybean yield (PROD).

\begin{tabular}{lccr}
\hline Variable & Angular coefficient & Linear coefficient & Determination coefficient \\
\hline SPR20 & 1.062 & -0.15 & 0.212 \\
SPR30 & 0.908 & 0.22 & 0.118 \\
SPR40 & 0.788 & 0.29 & 0.063 \\
U20 & 0.941 & 1.57 & 0.334 \\
U40 & 0.869 & 4.05 & 0.171 \\
PROD & 0.878 & 131.72 & 0.169 \\
\hline
\end{tabular}




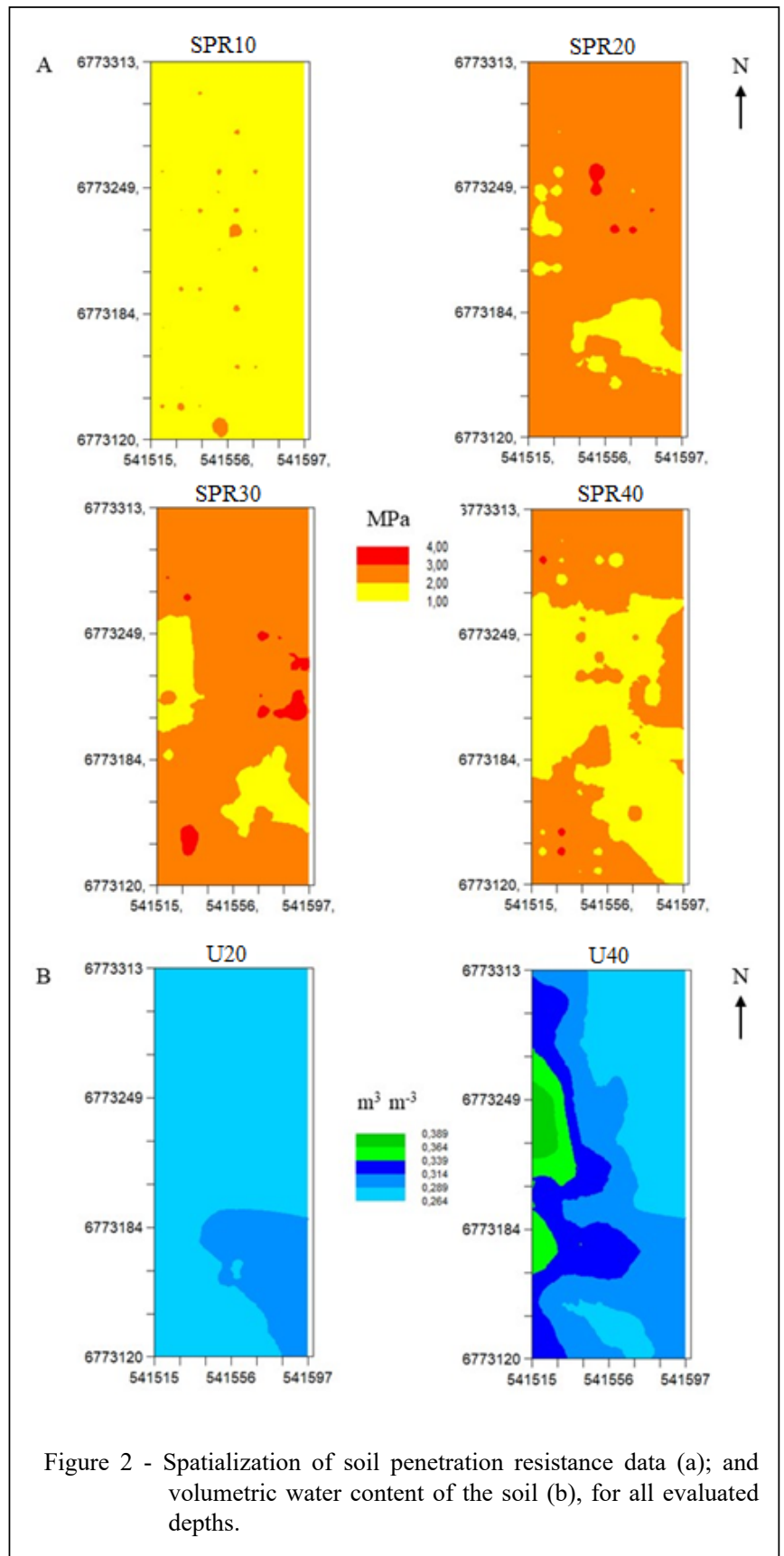

when compared to the SPR maps, it can be observed that the smaller SPR values at SPR20, SPR30, and SPR40 match the higher moisture values, based on the correlation data obtained. The soil penetration resistance is influenced by moisture, and any change to this attribute may modify the SPR data (BOTTEGA et al., 2013).

\section{CONCLUSION}

Soil penetration resistance has increased in depth, exceeding the critical limit for the normal development of the root system, between 0.05 and $0.35 \mathrm{~m}$.

No correlation was reported between the soil penetration resistance and soybean yield. However, 
there was a negative correlation between the penetration resistance and soil moisture at greater depths.

The smaller depth of soil penetration resistance presented a pure nugget effect, indicating a non-explained variability. The soil moisture and soybean yield semivariograms were the best structured, with an evident formation of a plateau.

For the conditions under which the experiment was conducted, the sample mesh of 10 $\mathrm{x} 10 \mathrm{~m}$ proved to be suitable for the evaluation of the spatial variability of soil penetration resistance, except for the depth of 0 to $0.10 \mathrm{~m}$, not justifying the use of a denser sampling mesh, in floodplain areas managed in a rotation system.

\section{ACKNOWLEDGEMENTS}

This research was financed in part by the Coordenação de Aperfeiçoamento de Pessoal de Nível Superior (CAPES), Brasil - Finance Code 001.

\section{DECLARATION OF CONFLICTS OF INTERESTS}

The authors declare no conflict of interest. The founding sponsor had no role in the design of the study; in the collection, analyses, or interpretation of data; in the writing of the manuscript, and in the decision to publish the results.

\section{AUTHOR'S CONTRIBUTIONS}

All authors contributed equally for the conception and writing of the manuscript.

\section{REFERENCES}

AMADO, T. J. C. et al. Spatial and temporal variability of grain yield under no-tillage cropping system. Pesquisa Agropecuária Brasileira, v.42, n.8 p.1101-1110, 2007. Available from: <https:// www.scielo.br/pdf/pab/v42n8/a06v42n8.pdf $>$. Accessed: May, 11, 2020. doi: 10.1590/S0100-204X2007000800006.

ANDRIOTTI, J. L. S. Fundamentos de Estatística e Geoestatística. São Leopoldo: Ed. UNISINOS, 2003. 165p.

BEUTLER, A. N. et al. Resistance to penetration and permeability of a typic dystrophic red latosol under management systems in the Cerrado region. Revista Brasileira de Ciência do Solo, v.25, n.1, p.167-177, 2001. Available from: <https://www.scielo.br/pdf/rbcs/ v25n1/18.pdf $>$. Accessed: May, 11, 2020. doi: 10.1590/S010006832001000100018 .

BEUTLER, A. N.; CENTURION, J. F. Resistance to penetration in oxisols: value limit to dry land rice yield. Ciência Rural, v.34, n.6, p.1793-1800, 2004. Available from: <https://www.scielo.br/pdf/ cr/v34n6/a19v34n6.pdf>. Accessed: May, 11, 2020. doi: 10.1590/ S0103-84782004000600019.

BOTTEGA, E. L. et al. Spatial and temporal variability of soybean productivity in Brazilian Savannah. Agrarian, v.6, n.20, p.167-
177, 2013. Available from: <http://ojs.ufgd.edu.br/index.php/ agrarian/article/view/1503/1416>. Accessed: May, 11, 2020. doi: 10.30612/agrarian.v6i20.1503.

CAMBARDELLA, C. A. et al. Field-Scale Variability of Soil Properties in Central Iowa Soils. Soil Science Society of America Journal, v.58, n.5, p.1501-1511, 1994.Available from:<https:// pubag.nal.usda.gov/catalog/18168>. Accessed: May, 11, 2020. doi: 10.2136/sssaj1994.03615995005800050033x.

CAMPOS, M. C. C. et al. Spatial variability of soil resistance to penetration and humidity in areas cultivated with cassava in the region of Humaitá, AM. RevistaAgro@mbiente On-line, v.6, n.1, p.09-16, 2012. Available from: <https://revista.ufrr.br/ agroambiente/article/view/689/654>. Accessed: May, 11, 2020 .doi:10.18227/1982-8470ragro.v6i1.689.

CANCIAN, L. C. Variabilidade espacial da resistência à penetração, granulometria e umidade do solo. 2015, 60p. Dissertação (Mestrado em Agronomia - Agricultura e Ambiente) - Universidade Federal de Santa Maria, Campus de Frederico Westphalen, Frederico Westphalen, 2015.

CARVALHO, L. A. et al. Resistance mechanics of the soil to penetration (RMP) under cane-of-sugar culture, in the city of Rio Brilhante-MS. Agrarian, v.1, n.2, p.7-22, 2008. Available from: $<$ http://ojs.ufgd.edu.br/index.php/agrarian/article/view/249/202>. Accessed: May, 11, 2020.

CHERUBIN, M. R. et al. Variabilidade da resistência a penetração do solo em função da dimensão da malha amostral. Revista Plantio Direto, v.125, n.5, p.4-9, 2011. Available from: <https:// www.falker.com.br/artigos/ArtigoAntonioLuisSanti_RPD125. pdf $>$. Accessed: May, 11, 2020.

DALCHIAVON, F. C. et al. Soybean yield and mechanical resistance to soil penetration under no-tillage in the Brazilian Savannah. Pesquisa Agropecuária Tropical, v.41, n.1, p.8-19, 2011. Available from: <https://www.scielo.br/pdf/pat/v41n1/ a02v41n1.pdf $>$. Accessed: May, 11, 2020. doi: 10.5216/pat. v41i1.8351.

DOnagema, G. K. et al. Manual de Métodos de Análise de Solo. Rio de Janeiro: Embrapa Solos, 2011. 230p. Available from: $<$ https://www.infoteca.cnptia.embrapa.br/infoteca/bitstream/ doc/990374/1/ManualdeMtodosdeAnilisedeSolo.pdf>.

GIRARDELLO, V. C. et al. Soil penetration resistance, efficiency of mechanical chisel plowing and soybean grain yield in a clayey oxisol under long-term no-till. Revista Brasileira de Ciência do Solo, v.38, n.4, p.1234-1244, 2014. Available from: $<$ https://www. scielo.br/pdf/rbcs/v38n4/20.pdf>. Accessed: May, 11, 2020. doi: 10.1590/S0100-06832014000400020.

GREGO, C. R.; VIEIRA, S. R. Spatial variability of soil physical properties on an experimental plot. Revista Brasileira de Ciência do Solo, v.29, n.2, p.169-177, 2005. Available from: $<$ https://www. scielo.br/pdf/rbcs/v29n2/24153.pdf>. Accessed: May, 11, 2020. doi: 10.1590/S0100-06832005000200002.

GREGO, C. R. et al. Geoestatística aplicada a Agricultura de Precisão. In: Bernardi, A. C. C. et al. Agricultura de Precisão: resultados de um novo olhar. Brasília: Embrapa, 2014. Cap.5, p.74-83. Available from: <https://ainfo.cnptia.embrapa.br/digital/ bitstream/item/114688/1/Agricultura-de-precisao-cap.5.pdf $>$. 
MESQUITA, M. G. B. F.et al. Statistical characterization of physical variables of soil. Acta Scientiarum: Agronomy, v.25, n.1, p.35-44, 2003. Available from: <http://periodicos.uem.br/ ojs/index.php/ActaSciAgron/article/view/2342/1629>. Accessed: May, 11, 2020. doi: 10.4025/actasciagron.v25i1.2342.

MOLIN, J. P. et al. Agricultura de Precisão. 1.ed. São Paulo: Oficina de Textos, 2015. 224p.

PARFITT, J. M. B. et al. Irrigação e drenagem para cultivo de soja e milho.In: EMYGDIO, B. M. et al. Cultivo de soja e milho em terras baixas do Rio Grande do Sul.1.ed. Brasília: Embrapa, 2017. Cap.3, p.45-78.

REICHARDT, K. et al. Variabilidade espacial de solos e experimentação de campo. Revista Brasileira de Ciência do Solo, v.10, n.1, p.1-6, 1986.

RICHART, A. et al. Soil compacting: causes and effects. Semina: Ciências Agrárias, v.26, n.3, p.315-338, 2005. Available from: $<$ http://www.uel.br/revistas/uel/index.php/semagrarias/ article/view/2319/1997>. Accessed: May, 11, 2020. doi: 10.5433/1679-0359.2005v26n3p321.

ROBERTSON, G.P. GS ${ }^{+}$: Geostatistics for the Environmental Sciences. Gamma Design Software, Plainwell, Michigan USA 2008. 179p.Available from: <https://geostatistics.com/files/ GSPlusUserGuide.pdf>.

SANTOS, H. G. dos et al. Sistema Brasileiro de Classificação de Solos. 5.ed. Rio de Janeiro: Embrapa Solos, 2018. 353p. Available from: $\quad<$ https://www.embrapa.br/solos/busca-de-publicacoes/-/ publicacao/1094003/sistema-brasileiro-de-classificacao-de-solos $>$.
SANTOS, M. H. F. et al. Estimativa da compactação através da resistência do solo a penetração em solo sob diferentes culturas e mata nativa. Revista Científica Eletrônica de Agronomia, v.14, n.27, p.49-62, 2015. Available from: <http://faef.revista. inf.br/imagens arquivos/arquivos destaque/8mCLLwccC bCMkub_2015-7-20-19-21-22.pdfhttp://faef.revista.inf.br/ imagens arquivos/arquivos destaque/8mCLLwccCbCMk ub_2015-7-20-19-21-22.pdf>. Accessed: May, 11, 2020.

SILVA, V. R. da et al. Spatial variability of the soil resistance to penetration in no tillage. Ciência Rural, v.34, n.2, p.399-406, 2004. Available from: <https://www.scielo.br/pdf/cr/v34n2/ a10v34n2.pdf $>$. Accessed: May, 11, 2020. doi: 10.1590/S010384782004000200010

SILVA, F. J. et al. Variabilidade espacial da resistência do solo à penetração e produtividade do milho. Revista de Agricultura Neotropical, v.4, n.3, p.77-84, 2017. Available from: $<$ https://pdfs.semanticscholar.org/f089/ ae1e6f3ddcf06fcab8ff50af3553c94bfc0f.pdf $>$. Accessed: May, 11, 2020. doi: 10.32404/rean.v4i3.1625.

TAVARES, U. E. et al. Spatial variability of penetration resistance and soil water content in Neossolo Flúvico. Water Resources and Irrigation Management, v.3, n.2, p.79-89, 2014. Available from: $\quad<$ http://www3.ufrb.edu.br/seer/index.php/wrim/article/ view/1627/859>. Accessed: Oct. 09, 2020. doi: 10.19149/23166886/wrim.v3n2p79-89.

WARRICK, A. W.; NIELSEN, D. R. Spatial variability of soil physical properties in the field. In: HILLEL, D. Applications of soil physics. New York: Academic Press, 1980. p.319-344. 